УДК 342.97

\title{
Вікторія Криворучко,
}

канд. юрид. наук,

старший викладач кафедри філософї, політології, психологї̈ і права

Одеської державної академії будівниитва та архітектури

\section{ОРГАНИ ВИКОНАВЧОЇ ВЛАДИ ЯК СУБ'ЄКТИ АДМІНІСТРАТИВНОГО УПРАВЛІННЯ}

У статті розглянуто актуальні питання визначення місия органів виконавчої влади серед суб'єктів адміністративного управління. Автор розглядає роль органів виконавчої влади в усій сукупності владної діяльності. Зроблено висновок про винятковість місия органів виконавчої влади в системі суб'єктів адміністративного управління.

Ключові слова: органи виконавчої влади, адміністративне управління, суб'єкти адміністративного управління.

Постановка проблеми. Виконавча влада виражена системою органів виконавчої влади, основним змістом діяльності яких є здійснення державного управління. Органи виконавчої влади розробляють основні напрями соціально-економічної політики держави, іï обороноздатності, безпеки, забезпечення громадського порядку та організують їх здійснення; організують управління державною власністю; виробляють заходи 3 проведення зовнішньої політики і виконують інші функції, покладені законодавством країни. Від результату діяльності цих органів насамперед залежить соціально-економічний та політичний стан країни. У цілому ці органи наділені широкими повноваженнями самостійної правотворчості, правозастосування та правоохорони. Проте досить часто органи виконавчої влади розглядають як суб'єктів адміністративного права, не звертаючи увагу на те, що вони також $є$ суб'єктами адміністративного управління.

Аналіз останніх досліджень і публікацій. Характеристиці суб'єктів адміністративного права присвятили свої праці I. А. Артеменко, О. М. Бандурка, В. М. Бевзенко, С. В. Ківалов, 3. Р. Кісіль, В. К. Колпаков, Р. С. Мельник, В. Д. Сорокін, М. М. Тищенко та ін. Разом із тим вказані вчені лише поверхнево розглядають органи виконавчої влади як суб'єктів адміністративного управління.

Метою цієї статті $\epsilon$ визначення кола суб'єктів виконавчої влади при здійсненні державного управління, а також вирішення питання щодо змісту, статусу, підстав діяльності органів виконавчої влади як суб'єктів адміністративного управління.

Виклад основного матеріалу. Управлінська або виконавча діяльність являє собою засновану на законах реалізацію відповідними органами державної влади функцій держави у сферах розвитку економіки і культури, соціального забезпечення та охорони здоров'я, транспорту і зв'язку, забезпечення безпеки держави та охорони громадського порядку, оборони країни і т. д.

Серед органів державної влади важливе місце посідають органи виконавчої влади, що здійснюють функції державного управління економічним, соціально-культурним, адміністративно-політичним будівництвом. Кожен із цих органів діє від імені та за дорученням держави, має певний правовий статус, виступає носієм відповідних повноважень юридично-владного характеру, реалізація яких забезпечує йому досягнення мети виконавчорозпорядчої діяльності. Отже, з точки зору теорії адміністративного права органи виконавчої влади здійснюють державно-управлінську діяльність і є суб'єктами державного управління як однієї з форм державної діяльності поряд із законодавчою і судовою [6, с. 106].

Як відомо, суб'єкт державного управління - це носій (володар) прав і обов'язків у сфері публічного права, передбачених адміністративно-правовими нормами, який здатний надані права реалізовувати, а покладені обов’язки виконувати [3, с. 218].

Звідси випливає, що «претендент» на статус суб'єкта адміністративного управління за своїми особливостями потенційно здатний бути носієм суб'єктивних прав і обов'язків у сфері публічного управління.

У загальнотеоретичному розумінні суб'єктом визнається носій предметно-практичної діяльності і пізнання (індивід або соціальна група), джерело активності, які спрямовані на об'єкт. Своєю чергою, у теорії права суб'єкт права - це особа (фізична або юридична), що за законом володіє здатністю мати 
і реалізовувати безпосередньо або через представника права і юридичні обов'язки (тобто правосуб'єктністю) [11, с. 116]. Говорячи про розкриття змісту дефініції «суб'єкт адміністративного управління», нам потрібно виходити з того, що основною (ключовою) формою реалізації владних повноважень є адміністративний процес [3, с. 82].

До суб'єктів адміністративного управління необхідно віднести учасників правових відносин, які виступають носіями суб'єктивних прав і обов'язків адміністративно-правового характеру. 3 теорії права відомо, що суб'єкти (як учасники правових відносин взагалі, так і адміністративних відносин зокрема), мають володіти правосуб'єктністю. Складниками змісту поняття адміністративної правосуб'єктності є потенційна здатність мати права і обов'язки у сфері публічного управління (адміністративна правоздатність), реалізовувати надані права і обов'язки у сфері публічного управління (адміністративна дієздатність), наявність суб'єктивних прав і обов'язків у сфері публічного управління [8, с. 64]

У сфері публічного управління суб'єктивні права і обов'язки мають як спільні ознаки, так і ознаки, що дають змогу їх розмежовувати.

Об'єднує їх спільна адміністративно-правова природа, існування в адміністративних правовідносинах, наявність меж у поведінці (i те, й інше є мірою), належність до осіб, які мають адміністративну правоздатність та адміністративну дієздатність.

Відмінності полягають у тому, що права реалізуються в інтересах їх носія, а обов’язки в інтересах інших осіб. Саме такими рисами і наділені органи виконавчої влади. По-перше, вони $€$ функціонально-галузевими носіями виконавчої влади в державі, а статус органу виконавчої влади закріплюється за ними в нормативному порядку; по-друге, є найважливішим складником органів державного управління і державного апарату в цілому (як відомо, державний апарат, крім органів державного управління, об'єднує управлінські структури законодавчої влади, органи правосуддя, прокуратури та інші державні органи); по-третє, вони об'єднані єдиним керівництвом і підпорядкуванням, внаслідок чого діють узгоджено і цілеспрямовано; по-четверте, кожен з органів цієї системи наділений державою специфічною компетенцією у сфері державного управління і реалізації державної виконавчої влади; по-п'яте, система органів виконавчої влади справляє регулюючий вплив на всі сфери державного і суспільного життя; по-шосте, в рамках своєї компетенції органи виконавчої влади самостійні в організаційному та функціональному відношеннях; по- сьоме, здійснюється специфічний вид державної діяльності, яка за своїм юридичним змістом $є$ виконавчо-розпорядчою [1, с. 34].

Щодо розуміння категорії «виконавчої влади» як різновиду державної влади у науковій літературі містяться досить різні підходи як за змістом, так і за формою. Так, А. С. Васильєв під органом державної виконавчої влади розуміє первинний елемент апарату державного управління, який утворюється державою для здійснення від іï імені завдань і функцій державної виконавчої влади [5, с. 78].

Деякі юристи-науковці розглядають орган виконавчої влади як один із елементів системи державного управління [12, с. 19].

Н. П. Матюхіна орган виконавчої влади визначає як частину державного апарату (організацію), яка має власну структуру та штат службовців, територіальний масштаб діяльності, утворюється в установленому законом або іншими правовими актами порядку і в межах передбаченої компетенції здійснює від імені і за дорученням держави функції державного управління в економічній, соціально-культурній, адміністративно-політичній сферах суспільного життя [4, с. 75-76].

Використання цього терміна пов'язане, передусім, із переходом до розподілу єдиної державної влади (певною мірою умовного) на три гілки влади - законодавчу, виконавчу, судову - згідно з функціонально-компетенційною спеціалізацією.

На основі зазначеного можна сформулювати визначення органу державної виконавчої влади: це носій державної виконавчої влади, що реалізує свою компетенцію в закріпленій сфері державного управління і має юридичний (нормативно зафіксований) статус органу державної виконавчої влади.

Не вдаючись у полеміку щодо визначення змісту поняття «виконавча влада», можемо констатувати, що остання здійснюється відповідними суб'єктами - органами виконавчої влади, які разом із організаційноструктурним механізмом становлять у своїй сукупності систему виконавчої влади.

Чітку вказівку на види органів виконавчої влади містить Конституція України. За ст. 113 вищим органом у системі органів виконавчої влади є Кабінет Міністрів України; ст. 114 вказує на існування центральних органів виконавчої влади (міністерств); ст. 118 визначає місцеві державні адміністрації як місцеві органи виконавчої влади [10, с. 141]. Крім зазначених у Конституції України, чинне законодавство наділяє статусом органів виконавчої влади без подальшого його уточнення Раду міністрів Автономної Республіки Крим (п. 1 ст. 35 Конституції Автономної Республіки Крим). 
Таким чином, органи виконавчої влади України поділяються на: а) вищі; б) центральні; в) місцеві; г) спеціальні [1, с. 16].

Вищим органом виконавчої влади $\epsilon$ Уряд України - Кабінет Міністрів. Він відповідальний перед Президентом України та підконтрольний і підзвітний Верховній Раді України. Кабінет Міністрів складає свої повно-важення перед новообраним Президентом України.

Центральними є ті органи, діяльність яких поширюється на всю територію України. До них можна зарахувати: Кабінет Міністрів України, міністерства, державні комітети, фонди тощо.

До центральних органів виконавчої влади належать ті, що керують відповідними галузями або здійснюють функціональне (міжгалузеве) управління та діяльність яких поширюється на всю територію України. Це міністерства; державні комітети (державні служби); центральні органи виконавчої влади зі спеціальним статусом. Робота центральних органів виконавчої влади спрямовується і координується Кабінетом Міністрів України [12, с. 116].

Центральний орган виконавчої влади узагальнює практику застосування законодавства 3 питань, що належать до його компетенції, розробляе пропозиції про вдосконалення законодавства та у встановленому порядку вносить їх на розгляд Президентові України, Кабінету Міністрів України. Центральний орган виконавчої влади в межах своїх повноважень на основі та на виконання актів законодавства видає накази, організує і контролює їх виконання.

Місцеві органи державної влади поширюють свою діяльність на конкретну адміністративно-територіальну одиницю. Вони виконують повноваження центральних органів виконавчої влади на території району, області, міста. Місцевим органам виконавчої влади належать повноваження приймати рiшення на певній території адміністративнотериторіальної одиниці. Систему місцевих органів виконавчої влади становлять обласні, Київська та Севастопольська міські державні адміністрації, а також підпорядковані їм відповідні районні, районні у містах Києві та Севастополі державні адміністрації [5, с. 86].

Здійснюючи свої повноваження, місцеві державні адміністрації керуються також іншими законами України, актами Президента України, Кабінету Міністрів України, органів виконавчої влади вищого рівня.

До спеціальних органів виконавчої влади належать органи, які не віднесені законодавством ні до вищих, ні до центральних, ні до місцевих, проте наділені статусом органу виконавчої влади. Органи спеціальної компетенції здійснюють керівництво 3 питань, які мають загальний характер для всіх чи багатьох галузей господарства.

До таких органів доцільно віднести Раду міністрів Автономної Республіки Крим, міністерства та інші органи, повноваження яких поширюються лише на територію автономної республіки. Вони здійснюють загальне або галузеве керівництво чи виконують окремі повноваження 3 управління об'єктами державної власності, які розташовані на території АРК.

Як уже зазначалося, органи державної виконавчої влади становлять найбільш численну групу державних органів. Взаємодіючи з іншими державними структурами, органами місцевого самоврядування та об'єднаннями громадян, вони перебувають у складній ієрархічній підпорядкованості та взаємозв'язку. Для кращого вивчення особливостей організації їхньої діяльності, а також для виявлення закономірностей у взаємозв'язках окремих органів визначають ознаки виконавчої влади.

Професор Ю. П. Битяк [2, с. 243] вказує на такі ознаки виконавчої влади:

- $€$ відносно самостійною гілкою єдиної державної влади в Україні - атрибутом державно-владного механізму, побудованого на засадах поділу влади;

- $є$ самостійною лише у зв'язку з практичною реалізацією Конституції, законів України;

- вона має державно-правову природу, наділена владними повноваженнями, що виявляється в їі можливостях впливати на поведінку і діяльність людей, їх об'єднань;

- здійснюється на засадах поділу влади на гілки не на всіх рівнях, а лише на вищому, оскільки на місцевому рівні відсутні законодавчі органи: на рівні району в місті $є$ судові органи, водночас відсутні органи виконавчої влади (державного характеру), крім Києва та Севастополя, немає їх і на рівні села, селища, міста (управління на цьому рівні здійснюється органами місцевого самоврядування);

- виконавча влада не може ототожнюватися 3 виконавчою діяльністю, оскільки така діяльність є формою реалізації виконавчої влади, видом державної діяльності відповідної компетенції та функціональної спрямованості;

- виконавча влада здійснюється системою спеціально створених суб'єктів - органів виконавчої влади різних рівнів, які наділені виконавчою компетенцією, що не властиве органам законодавчої та судової влади. 
Узявши за основу запропоновану систему ознак, український науковець С. П. Кисіль [9, с. 7] до в ознак виконавчої влади зараховуе:

- організуючий характер виконавчої влади. При цьому він пояснює, що якщо державна влада загалом стосовно суспільства виступає як основний інститут соціального управління, то виконавчу владу можна охарактеризувати як основний інститут державного управління. На його думку, організаційний аспект виконавчої влади виявляється в усіх сферах суспільних відносин та зв'язків, на які впливає державне управління: економічній, політичній, соціальній, культурній, національній, охоронній тощо. Виконавча влада безпосередньо організовує внутрішній правопорядок, оборону, суспільну і державну безпеку, здійснює організаційні, координаційні та контрольні функції стосовно найрізноманітніших явищ суспільного життя;

- постійність (безперервність) дії виконавчої влади. Тобто виконавча влада, відповідаючи вимогам динамічного розвитку суспільних процесів, діє постійно і цілеспрямовано, перебуваючи у постійній взаємодії з ними, стикається з новими суспільними явищами;

- прерогативний характер виконавчої влади. Поява нових, не врегульованих чинним законодавством суспільних відносин викликає необхідність їх негайної регламентації органами виконавчої влади;

- універсальний характер виконавчої влади. Виконавча влада здійснюється на території держави всюди, де проживають люди, де виникають суспільні відносини. Межі виконавчої влади збігаються 3 кордонами держави. Універсальність виконавчої влади виявляється і в здійсненні правотворчості шляхом прийняття різних підзаконних нормативних актів, які уточнюють, деталізують, застосовують закон до конкретних суспільних відносин та в юрисдикційній діяльності у вигляді застосування уповноваженими на це органами (посадовими особами) адміністративних чи дисциплінарних стягнень.

- предметний характер виконавчої влади, тобто наявність у розпорядженні виконавчої влади значних ресурсів: правових, інформаційних, економічних, технічних, ідеологічних, що забезпечують реальність організаційно-управлінського впливу на суспільні процеси. У безпосередньому розпорядженні виконавчої влади перебувають збройні сили, міліція, установи виконання покарань, що надає суб'єктам виконавчої влади можливість використовувати наявні у них фактичні та правові можливості здійснення адміністративного примусу.
- наявність ієрархічно побудованого, чітко структурованого апарату виконавчої влади.

Отже, в аспекті ознак органи виконавчої влади є персоніфікованим суб'єктом адміністративного управління і носієм виконавчої влади, що має чітко визначену нормативноправовим шляхом компетенцію щодо відповідної групи суспільних відносин, під час реалізації яких приймає владні (юридично обов'язкові) рішення і здійснює інші юридично значимі дії.

Діяльність виконавчої влади за своїм змістом є не що інше, як виконання загальних функцій, що виникають у процесі спільної праці, а за способом здійснення - це владна діяльність.

Державно-владні повноваження виражаються в компетенції органів виконавчої влади і практично реалізуються у прийнятих ними владних рішеннях. Вони оформлюються у вигляді юридично обов'язкових нормативних й індивідуальних правових актів, що видаються ними від імені держави, а також знаходять своє відображення в конкретних діях і заходах, що здійснюються [11, с. 271].

На виконання прийнятих рішень органи виконавчої влади здійснюють контроль нагляд за неухильним дотриманням вимог, що містяться в актах управління. При цьому вони спираються на інтелектуальну, організаційну, матеріальну і примусову силу держави. Захист цих вимог від порушень вони забезпечують шляхом застосування різноманітних заходів виховання, переконання, роз'яснення і заохочення, а в разі потреби - i державного примусу.

Головна мета виконавчої влади зумовлена іiї соціальним призначенням і особливим становищем у системі розподілу влад - якісне виконання завдань і функцій державного управління. Таким чином, функції виконавчої влади визначаються цілями і функціями державного управління. Ю. М. Старілов зазначає, що сутність функцій виконавчої влади виявляється під час аналізу їі результатів, які досягаються в процесі здійснення цієї влади [7, с. 209].

\section{Висновки.}

Серед суб'єктів адміністративного управління органи виконавчої влади займають визначальне (ключове) місце та суттєво впливають на здійснення публічного адміністрування загалом, адже беруть участь в усіх видах адміністративних проваджень. Органи виконавчої влади (державного управління) - це організований колектив, який утворює самостійну частину державного апарату, наділений компетенцією, виконує публічну 
функцію, структура і діяльність якого регламентується нормами права.

Необхідно підкреслити, що органам виконавчої влади властива саме сукупність усіх перерахованих особливостей, ix суворе поєднання. Законодавчі органи творять закони, органи виконавчої влади iх виконують, втілюють у життя. Органи виконавчої влади, як суб'єкти адміністративного управління, наділені правом приймати рішення на свій розсуд, але в рамках закону, і видавати нормативні правові акти, а також ненормативні акти. Усі вони повинні грунтуватися на законах i, відповідно, конкретизувати і розвивати їх, тобто бути підзаконними. Діяльність із видання підзаконних нормативних актів та їх реалізації називається розпорядчою.

\section{Список використаних джерел:}

1. Авер'янов В. Б. Органи виконавчої влади в Україні / В. Б. Авер'янов; НАН Укр. : Ін-т держави ім. Корецького. - К. : ІнЮре, 1997. - 48 с.

2. Адміністративне право України / за ред.

Ю. П. Битяка. - Х.: Право, 2000. - 520 с.

3.Алфьоров С. М. Адміністративне право : навчальнийпосібник /С.М.Алфьоров.-К.:Центручбової літератури, 2011. - 216 с.
4. Битяк Ю. П. Адміністративне право України : підручник / [Ю. П. Битяк, В. М. Гаращук, В. В. Богуцький та ін.] ; за заг. ред. Ю. П. Битяка, В. М. Гаращука, В. В. Зуй. - 2-ге вид., перероб та доп. - Х.: Право, 2013. - 656 с.

5.Васильев А. С. Административное право Украины / А. С. Васильев. - Х.: Одисей, 2001. $-143 \mathrm{c}$

6. Волинка К. Г. Теорія держави і права : навчальний посібник / К. Г. Волинка. - К., 2003. $-240 \mathrm{c}$

7. Державне управління: теорія і практика / за заг. ред. В. Б. Авер' янова. -К., 1998. - 432 с.

8. Ківалов С. В. Адміністративне право України : навчально-методичний посібник / С. В. Ківалов, Л. Р. Біла. - Одеса : Юридична література, 2002. - 312 с

9. Кисіль С. П. Центральні органи виконавчої влади України: стан і розвиток : наукове видання / С. П. Кисіль. - К., 1999. -80 с.

10. Конституція України від 28 червня 1996 р. // Відомості Верховної Ради України. 1996. - № 30. - C. 141 .

11. Кузьменко О. В. Курс адміністративного процесу : навчальний посібник / О. В. Кузьменко. - К.: Атіка, 2007. - 416 с.

12. Нижник Н. Р. Системний підхід в організації державного управління : навчальний посібник / Н. Р. Нижник, О. А. Машков. - К., 1998. - 159 c.

В статье рассмотрены актуальные вопросы места органов исполнительной власти среди субъектов административного управления. Автор рассматривает роль органов исполнительной власти во всей совокупности управленческой деятельности. Сделан вывод об исключительности органов исполнительной власти в системе субъектов административного управления.

Ключевые слова: органы исполнительной власти, административное управление, субъекты административного управления.

The article examines current issues determining local of executive power bodies among the subjects of administrative management. The author examines the role of the executive bodies among the whole set of managerial activities. As a result, the article concluded exclusivity local executive power bodies in the system of administrative.

Key words: executive authorities, administrative management, subjects of administrative management. 